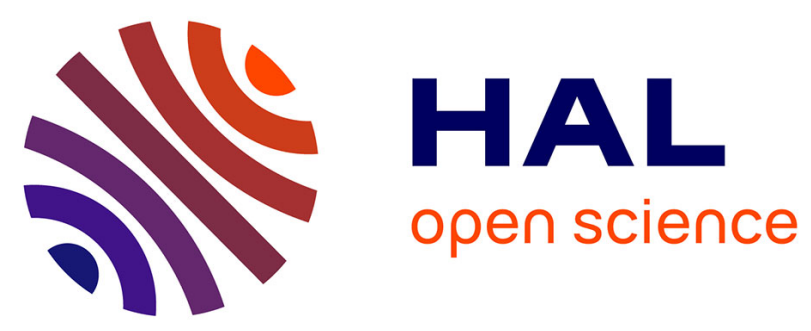

\title{
Is GHG mitigation policy enough to develop bioenergy in Asia: a long-term analysis with TIAM-FR
}

\author{
Seungwoo Kang, Sandrine Selosse, Nadia Maïzi
}

\section{To cite this version:}

Seungwoo Kang, Sandrine Selosse, Nadia Maïzi. Is GHG mitigation policy enough to develop bioenergy in Asia: a long-term analysis with TIAM-FR. International Journal of Oil, Gas and Coal Technology, 2017, Special Issue on: IBSCE 2015 Bioenergy and Biofuels in Asia and Europe, 14 (1/2), pp.5-31. 10.1504/IJOGCT.2017.10002111 . hal-01419991

HAL Id: hal-01419991

https://hal-mines-paristech.archives-ouvertes.fr/hal-01419991

Submitted on 18 Jan 2018

HAL is a multi-disciplinary open access archive for the deposit and dissemination of scientific research documents, whether they are published or not. The documents may come from teaching and research institutions in France or abroad, or from public or private research centers.
L'archive ouverte pluridisciplinaire HAL, est destinée au dépôt et à la diffusion de documents scientifiques de niveau recherche, publiés ou non, émanant des établissements d'enseignement et de recherche français ou étrangers, des laboratoires publics ou privés. 


\title{
Is GHG mitigation policy enough to develop bioenergy in Asia: a long-term analysis with TIAM-FR
}

\section{Seungwoo Kang*, Sandrine Selosse and Nadia Maïzi}

CMA - Centre for Applied Mathematics, MINES ParisTech, PSL Research University, CS 10207 rue Claude Daunesse, 06904 Sophia Antipolis Cedex, France

Email: seungwoo.kang@mines-paristech.fr Email: sandrine.selosse@mines-paristech.fr Email: nadia.maizi@mines-paristech.fr

Corresponding author *

\begin{abstract}
Asian countries have sharply increased their energy consumption due to economic growth, inducing extremely high dependency on fossil energy, ranking them among the world's highest $\mathrm{CO}_{2}$ emitters. Hence, the current focus in these countries is on using bioenergy to diversify the energy mix and mitigate climate change. In this study, we estimated the evolution of bioenergy deployment through current energy and climate policies using a bottom-up energy system optimisation model. The results indicate that a carbon tax system would derive the greatest bioenergy consumption by 2030 . Current INDCs targets appear insufficient to promote bioenergy development without renewable energy targets and biofuel blending mandates. [Received: January 14, 2016; Accepted: July 24, 2016]
\end{abstract}

Keywords: bioenergy; climate change; climate action plan; strategy; policies; energy system; long-term modelling.

Reference to this paper should be made as follows: Kang, S., Selosse, S. and Maïzi, N. (2017) 'Is GHG mitigation policy enough to develop bioenergy in Asia: a long-term analysis with TIAM-FR', Int. J. Oil, Gas and Coal Technology, Vol. 14, Nos. 1/2, pp.5-31.

Biographical notes: Seungwoo Kang is a $\mathrm{PhD}$ student at the Centre for Applied Mathematics of MINES Paris Tech. His PhD research is on 'Bioenergy market and stress to water: implementation in the integrated model TIAM-FR'. He holds two Masters in Environmental Engineering from École des Ponts ParisTech and in Environmental Economics from MINES ParisTech.

Sandrine Selosse is a Senior Researcher at the Centre for Applied Mathematics of MINES ParisTech. After a PhD in Economy, she joined MINES ParisTech to work on the articulation of economy-resources-climate factors and on the synergy between bottom-up and top-down models. She has a central role in the development of the ETSAP-TIAM family of models and in particular the TIAM-FR model and she animates the Chair 'Prospective Modeling for Sustainable Development'. Her areas of expertise are energy system modelling, carbon capture and storage, biomass and climate policy.

Nadia Maïzi is the Head of the Centre for Applied Mathematics of MINES ParisTech. She intervenes as optimisation expert for industrial companies or government commissions and is the official representative for France for the IEA/ETSAP program. At MINES ParisTech, she leads a team of 45 researchers and $\mathrm{PhD}$ students. Her expertise ranges from general mathematical computation to modelling markets and prospective analysis. She is cofounder of an industrial Chair 'Prospective Modeling for Sustainable Development' supported by several industrial partners. 
This paper is a revised and expanded version of a paper entitled 'What development for bioenergy in Asia: a long-term analysis of the effects of policy instruments using TIAM-FR model' presented at International Bioenergy (Shanghai) Exhibition and Asian Bioenergy Conference, Shanghai, China, 21-23 October 2015.

\section{Introduction}

Over the last few decades, Asian countries have drastically increased their energy consumption due to fast economic development and growing populations. The extended world energy balances (IEA, 2013) produced by the International Energy Agency (IEA) show that total primary energy supply (TPES) in Asia - of which about $72 \%$ of energy consumption came from four Asian countries, China, India, Japan and South Korea represented over $44 \%$ in the world in 2011. China and India in particular have shown a tremendous increase in energy consumption in recent years. From the same source, in 2011, the energy consumption levels of China and India increased by $233 \%$ and $164 \%$, respectively compared to 2000 . Along with the sharply increasing trend and high level of energy consumption in these countries, the share of fossil fuel in their energy mix is highly dominant, at $89.6 \%$ for Japan, $88.3 \%$ for China, $82.8 \%$ for South Korea and $72.3 \%$ for India. Nevertheless, these countries possess insufficient fossil energy resources, spurring them to decrease their fossil energy dependency and diversify their energy mix by developing bioenergy and other renewable energy sources. In addition, the greenhouse gas (GHG) emissions generated by fossil energy combustion in these countries rank them as the world's biggest emitters of GHG.

Given growing concerns about climate change, bioenergy is attracting increasing attention as one of the most interesting alternatives to fossil energy. This is illustrated by the number of ambitious bioenergy promotion policies currently being implemented in the four countries studied (Kang et al., 2015). Furthermore, at the recent United Nations Conference on climate change, the 21st Conference of Parties (COP 21) held in Paris, France, in 2015, each country established national GHG emission targets until 2030 with the aim of mitigating global climate change. However, the relationship between bioenergy deployment and GHG mitigation policy in a harmonised energy system has not been clearly identified.

Therefore, this study aims to discuss how different political tools encourage or discourage bioenergy development, especially for the largest contributors to GHG emissions in Asia, i.e., China, India, Japan and South Korea. More precisely, using a long-term bottom-up energy system optimisation model, TIAM-FR, a TIMES family model from Energy Technology Systems Analysis Program (ETSAP)/IEA, we 
investigated the effects on bioenergy development of different national and global GHG pledges, combined or not with specific bioenergy promotion policies, and with economic instruments, such as a carbon tax system.

\section{Methodology}

We evaluated the future of bioenergy in Asia through scenario analysis. Several different scenarios were analysed and compared with the current bioenergy policies of four Asian countries, China, India, Japan and South Korea, for the period 2005-2050. This long-term analysis was performed with a bottom-up energy system optimisation model, TIAM-FR, developed by the MINES ParisTech's Centre for Applied Mathematics (Selosse and Maizi, 2014).

\subsection{Presentation of TIAM-FR}

TIAM-FR is the French version of ETSAP-TIAM, the world energy system model developed under the IEA's Energy Technology Systems Analysis Program (ETSAP) under the TIMES paradigm (Labriet et al., 2008). This global multi-regional model is based on a bottom-up approach and a technology-rich representation of the energy system, which consists of different energy resources, forms, energy transformation technologies and end uses.

Figure 1 Energy system structure in TIAM-FR (see online version for colours)

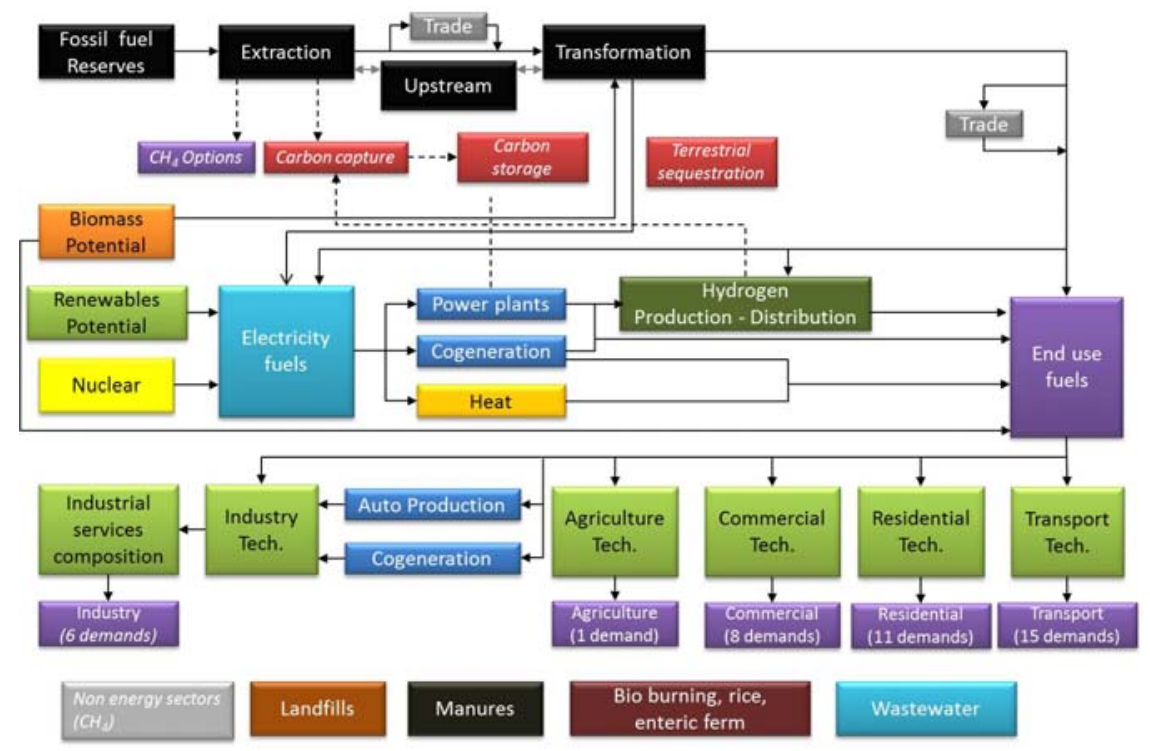

The model covers the entire world, split into 15 regions [Australia-New Zealand (AUS); Canada (CAN), United States of America (USA), Western Europe (EU-15, Iceland, Malta, Norway and Switzerland (WEU), Eastern Europe (EEU), Japan (JPN), India (IND), China (includes Hong Kong, excludes Chinese Taipei, CHI), Africa (AFR), 
Central and South America (CSA), Middle-East (includes Turkey, MEA), Mexico (MEX), South Korea (SKO), other developing Asian countries (includes Chinese Taipei and Pacific Islands, ODA), former Soviet Union (includes the Baltic states, FSU)], with a separate representation of China, India, Japan and South Korea.

Furthermore, the model has five energy service sectors (agriculture, industry, commercial, residential, transport), which are estimated based on socio-economic assumptions specified by user (GDP, household, population, sectorial growth, industrial production, etc.) over the time horizon. Examples of the 41 demands in all energy sectors are: lighting, water heating, space cooling, cooking etc. for residential and commercial sectors; tons of aluminium, iron and steel, etc. to be produced for the industrial sector; and vehicle-km to be driven by car, bus, etc. for the transport sector.

Techno-economic characteristics are integrated into the model to describe more than one thousand technologies in all sectors at each stage of the energy chain (extraction, conversion, processing, transmission and end uses) and one hundred commodities (energy forms, materials, emissions) in each region. These technologies and commodities are interrelated in a reference energy system. The reference energy system in Figure 1 represents the entire energy flow, from fossil fuel reserves, biomass, renewables and nuclear potentials, to end uses from energy service demands, and including the conversion of energy sources to primary and final forms, as well as processing and trading.

This model is a linear programming model estimating an inter-temporal partial economic equilibrium on integrated energy markets, which aims to minimise, under environmental and technical constraints, the discounted global energy system cost over the entire model time horizon until 2100 by making decisions on equipment investment, equipment operation, primary energy supply, and energy trade (Selosse and Garcia, 2014). Partial equilibrium models commonly configure the production and consumption of commodities as well as the prices. The production cost of a commodity affects its demand and, simultaneously, the demand affects the commodity's price. The TIAM model computes the flows of energy forms and materials, and also their prices. Thus, the amount of energy production is equal to consumer demand. This supply-demand equilibrium is presented at each stage of the entire integrated energy system, for example, primary energy production, secondary energy production, and final energy services. This feature maximises the net total economic surplus, which is described as the sum of suppliers and consumer surpluses through the equilibrium of all energy markets. The use of partial equilibrium allows us to capture most of the feedback from the economy into the energy system (Loulou et al., 2005a).

The model calculates the net present values of total cost for each region with the following objective function:

$$
N P V=\sum_{r=1}^{R} \sum_{y \in Y E A R S}\left(1+d_{r, y}\right)^{R E F Y R-y} * \operatorname{ANNCOST}(r, y)
$$

where $N P V$ is the net present value of the total cost for all regions over the projected period; $\operatorname{ANNCOST}(r, y)$ is the total annual cost in region $r$ and year $y$; $d_{r, y}$ is the discount rate; REFYR is the reference year for discounting; YEARS is the set of years and $R$ is the set of regions (15 regions). Annual costs mainly consist of investment costs, taxes and subsidies on investment, decommissioning capital costs, fixed and variable operation and maintenance costs, taxes and subsidies on capacity, salvage value, cost of demand 
reductions (welfare loss), and late revenues from endogenous commodity recycling after the end of the horizon. We also use the economic life of a process and sector-dependent hurdle rates to annualise investments and decommissioning capital costs. The hurdle rates, which range from $6 \%$ to $9 \%$ per year for large utilities and heavy industries, to more than $25 \%$ per year for the residential, commercial and private transport sectors, were collected from the European Union integrated project NEEDS (Loulou et al., 2005b). These annualised costs complete the total annual costs with the annual costs of fixed and variable costs. Lastly, the total annual costs are discounted to the model's reference year, 2005, using the general discount rate of 5\%. The chosen discount rate is in line with the literature on the cost of climate change abatement and most long-term integrated models; for example, IMAGE model (van Vuuren et al., 2010), FAIR-SiMCap model (van Vliet et al., 2012), MESSAGE model (den Elzen et al., 2010, 2011) adopted the same discount rate of $5 \%$.

The results of the optimisation are: the structure of the energy system for each region, i.e., type and capacity of energy technologies, energy consumption by fuel, development of emissions, energy trade flows between regions, along with the resulting transport capacities required, and detailed energy system costs, plus information on the marginal costs of environmental measures. In terms of environmental measures, the model computes $\mathrm{GHG}$ emissions $\left(\mathrm{CO}_{2}, \mathrm{CH}_{4}\right.$ and $\left.\mathrm{N}_{2} \mathrm{O}\right)$ from fuel combustion and processes and its reduction comes from endogenous demand reductions, technology progress such as energy efficiency improvements, and changes in processes, as well as introduction of carbon sequestration technologies (Selosse et al., 2010).

\subsection{Energy-climate scenarios}

In this study, several different climate scenarios are explored for four countries (China, India, Japan and South Korea). The Table 1 presents the different GHG emission targets applied to this scenario.

Table 1 Summary of developed scenarios

\begin{tabular}{|c|c|}
\hline Scenario & Description \\
\hline$B A U$ & No environmental constraints \\
\hline Global_Factor2_GHG & $50 \%$ global GHG reduction compared to 2005 only \\
\hline$I N D C$ & National GHG target scenario from INDCs reports \\
\hline$I N D C+R N W+B I O F U E L$ & $\begin{array}{l}\text { National GHG target scenario from INDCs reports } \\
+ \text { renewable energy target } \\
\text { + biofuel blending or production target }\end{array}$ \\
\hline Carbon tax & $\begin{array}{l}\text { Carbon tax only without GHG reduction target } \\
\text { - low: } \$ 100 / \mathrm{tCO}_{2} \text { eq by } 2030 \\
\text { - high: } \$ 200 / \mathrm{tCO}_{2} \text { eq by } 2030\end{array}$ \\
\hline
\end{tabular}

These GHG emission targets are recalculated in this paper in order to derive only domestic GHG emission targets excluding the planned use of imported carbon credits.

A business as usual (BAU) scenario is first developed and calculated. This baseline scenario without any emission constraint outlines some key patterns in the evolution of the energy system, and serves as the starting point for comparing different avenues of carbon mitigation over the period 2005-2050. Under the BAU scenario, GDP growth 
about $2.3 \%$ of moderate annual economic growth) and world population growth (up to 9 billion by 2100), which are close to Intergovernmental Panel on Climate Change (IPCC) B2 scenario, are applied as demand projection drivers (Biberacher and Gadocha, 2012; Labriet et al., 2008; Loulou, 2007).

Secondly, the GHG emission reduction scenario at global scale is imposed. This scenario, named Global_Factor2_GHG scenario, consists in reducing GHG emissions by $50 \%$ by 2050 compared to 2005 . This climate constraint is compatible with the representative concentration pathways (RCP) 2.6 scenario in IPCC's fifth assessment report (AR5) to limit global warming to less than $2^{\circ} \mathrm{C}$ until 2100 (IPCC, 2014). More precisely, IPCC's RCP2.6 scenario demands a change in $\mathrm{CO}_{2}$ eq emissions compared to 2010 in the range of $-72 \%$ to $-41 \%$ in 2050 , as well as $\mathrm{CO}_{2}$ eq concentrations in 2100 of about $450 \mathrm{ppm}$. In the TIAM-FR model, the global $\mathrm{CO}_{2}$ eq emission target, which is imposed by this scenario, distributes internally to each region to optimise the cost of the global energy system.

Prior to the recent climate change convention, Conference of Parties (COP 21) held in Paris, France in 2015, 155 countries including China, India, Japan and South Korea submitted their intended nationally determined contributions (INDCs) reports to the United Nations Framework Convention on Climate Change (UNFCCC) secretariat. Each INDCs report contains GHG mitigation pledges and action plans until 2025 or 2030 to limit the increase in average global temperature to less than $2^{\circ} \mathrm{C}$ by 2100 . During the COP 21, parties agreed to update their nationally determined contributions by 2020 , and then again every five years (UNFCCC, 2015). We applied the national GHG emission pledges communicated in the first INDCs reports by the end of 2015 to trace bioenergy development. Hence, based on the INDCs reports of the four countries studied (China, 2015; India, 2015; Japan, 2015; Republic of Korea, 2015), two other scenarios have been developed in this study. The first one, called 'INDC', only applies the GHG emission reduction targets until 2030 to investigate the bioenergy deployment level without any other mandates. This scenario allows us to analyse how stand-alone GHG pledges impact on bioenergy development compared to BAU scenario results. Table 2 presents the different GHG emission targets applied to this scenario.

In the case of Japan, the GHG emission reduction target established in its INDCs report (Japan, 2015) is a decrease of $26 \%$ by 2030 compared to 2013 (25.4\% compared to 2005). Concerning energy-oriented $\mathrm{CO}_{2}$ emissions, Japan set a target to reduce emissions by $24 \%$ by 2030 compared to 2005 levels. Furthermore, the Japanese government plans to offset the country's emissions in the range of 50 to 100 million $\mathrm{tCO}_{2}$ with the Japanese crediting mechanism (JCM), which achieves $4-8 \%$ of their target based on energy-oriented emissions of 1,219 million $\mathrm{tCO}_{2}$ in 2005. Therefore, Japan's domestic emissions pledge, excluding carbon offset from the credit scheme, was recalculated to show a reduction of between $16 \%$ and $20 \%$ by 2030 compared to 2005 and applied in our scenario. South Korea announced a mitigation target of a 37\% reduction in GHG emissions by 2030 compared to BAU level. However, similar to Japan, the Ministry of Environment of South Korea communicated in its official press that an $11.3 \%$ emissions reduction will be achieved through the international carbon crediting system (Choi, 2015). Hence, we recalculated domestic GHG emission targets, resulting in a $25.7 \%$ reduction by 2030 and input this figure into our scenario. Unlike the GHG emission limits in absolute value established by Japan and South Korea, China and India set targets to reduce the emission intensity of their GDP. China proposed to decrease $\mathrm{CO}_{2}$ intensity of GDP by $60-65 \%$ by 2030 compared to 2005 , excluding other GHG emissions such as 
$\mathrm{CH}_{4}$ and $\mathrm{N}_{2} \mathrm{O}$. India is aiming to reduce $33-35 \%$ of the $\mathrm{GHG}$ emissions intensity of its GDP, which includes $\mathrm{CH}_{4}$ and $\mathrm{N}_{2} \mathrm{O}$ by 2030 compared to 2005 levels.

Table 2 GHG emission reduction targets applied to the scenario INDC

\begin{tabular}{lccccc}
\hline Country & $\begin{array}{c}\text { Reference } \\
\text { year }\end{array}$ & $\begin{array}{c}\text { Target } \\
\text { year }\end{array}$ & Target & Unit type & $\begin{array}{c}\text { GHG } \\
\text { mitigation } \\
(2005-2030)\end{array}$ \\
\hline China & 2005 & 2030 & $60-65 \%$ & $\mathrm{CO}_{2}$ intensity of GDP & $61 \%$ \\
India & 2005 & 2030 & $33-35 \%$ & GHG intensity of GDP & $113 \%$ \\
Japan & 2005 & 2030 & $16-20 \%$ & GHG $\left(\mathrm{tCO}_{2} \mathrm{eq}\right)$ & $-20 \%$ \\
South Korea & BAU (2030) & 2030 & $25.7 \%$ & GHG $\left(\mathrm{tCO}_{2} \mathrm{eq}\right)$ & $-14 \%$ \\
\hline
\end{tabular}

Source: Recalculated INDCs UNFCCC targets by author

The second scenario, called ' $I N D C+R N W+B I O F U E L$ ', combines GHG emission targets with renewable and bioenergy supply targets. Renewable and bioenergy targets are principally retrieved from INDCs reports and completed by research on external national policies. Currently, biofuel is considered as one of the easiest options to replace conventional fossil energies (gasoline and diesel) in the transport sector, whose contribution to national GHG emissions is rising significantly in these countries. Consequently, the four countries have implemented biofuel promotion policies by mandating a minimum blending rate of biofuel in fossil fuel. As a result, we needed to apply these policies to our scenario in order to investigate changes in the future energy system.

Table 3 Renewable energy targets and biofuel blending mandates

\begin{tabular}{ll}
\hline Country & \multicolumn{1}{c}{ Target } \\
\hline China & $15 \%$ of non-fossil energy in TPES by 2020 and $20 \%$ by 2030 \\
& $10 \%$ minimum blending rate of bioethanol in gasoline by 2015 \\
India & $40 \%$ of power supply capacity from renewables in 2030 \\
& $20 \%$ minimum blending rate of biofuel \\
Japan & Solar $7 \%$, wind $1.7 \%$, geo $1.1 \%$, hydro $9.2 \%$, biomass $4.6 \%$ by 2030 (Japan, 2015) \\
& Maximum blending rates: $10 \%$ bioethanol, $5 \%$ biodiesel \\
South & $11.7 \%$ renewables by 2029 \\
Korea & $3 \%$ minimum blending rate of biodiesel by $2020 ; 5 \%$ by 2030 \\
\hline
\end{tabular}

Japan and South Korea did not mention biofuel alternatives in their INDCs communication unlike China and India. We therefore carried out additional research on biofuel policies to complete this second scenario. According to our policy survey, South Korea mandated a minimum biodiesel blending rate of 3\% by 2020 and 5\% by 2030 RFS (Renewable Fuel Standard) through an amendment of the law 'The Act on the Promotion of the Deployment, Use and Diffusion of New and Renewable Energy', which was implemented on 31 July 2015 (Korea Energy Agency, 2015a). In the same law, the government of South Korea plans to increase the renewable energy share in electricity generation by up to $11.7 \%$ until 2029 through its renewable portfolio standard (RPS) and 'Seventh Electricity Supply Plan' (Korea Energy Agency, 2015b). In Japan, in order to avoid a potential drop in vehicle performance, its gasoline quality assurance law established a maximum blending rate of bioethanol and biodiesel of $3 \%$ for bioethanol 
and $5 \%$ for biodiesel. However, the law has been revised with the aim of promoting biofuel, establishing a 10\% maximum blending rate of bioethanol for new automobiles, which is compatible with E10 (Iijima, 2014).

In the case of China, an increase in the share of non-fossil energy is one of the major climate action plans mentioned in its INDCs report (China, 2015). China aims to boost $20 \%$ of its TPES with renewable energy by 2030 . In our scenario, as previously, the Chinese government proposes to increase the renewable energy share in TPES by up to $15 \%$ by 2020 (Jian-Kun, 2015). We therefore applied a progressive renewable energy target by implementing $15 \%$ by 2020 and $20 \%$ by 2030 . The Indian government has set a target to increase power supply capacity from renewable energies by up to $40 \%$ by 2030 , with a $20 \%$ minimum biofuel blending rate in the same period (India, 2015).

The carbon tax system and cap-and-trade (emission trading scheme, ETS) are the main economic instruments to address climate change mitigation. The ETS scheme requires an initial allocation of allowances based on GHG mitigation targets, while carbon tax only imposes a pricing mechanism. In addition, in these countries, the integration of the national carbon market into the global market is still far from current, given the immature market condition. In addition to these direct GHG emission constraints, an economic instrument to reduce GHG emissions was implemented in this study. More precisely, we analysed the effect of economic instruments on bioenergy pathways and GHG emission levels without imposing a direct upper limit on emission quantity. Hence, carbon tax scenarios were calculated to estimate the different pathways of bioenergy deployment and the evolution of GHG emissions under a carbon tax mechanism, which does not guarantee targeted GHG emissions but assures cost-effective GHG mitigation.

Table 4 Carbon tax levels

\begin{tabular}{lccc}
\hline Unit: $\$ / \mathrm{tCO}_{2} e q$ & 2020 & 2030 & 2050 \\
\hline Low tax & 80 & 100 & 270 \\
High tax & 150 & 200 & 530 \\
\hline
\end{tabular}

According to the forth assessment report of IPCC (IPCC, 2007), the optimal tax rate was estimated in the range of $\$ 3$ and $\$ 95$ for 2005 . This globally aggregated range was deemed to be an underestimation due to a lack of quantifiable estimation. Another study on global GHG abatement cost (McKinsey \& Company, 2010) estimated from $€ 80$ ( $\$ 117$ in real 2008 prices) to $€ 100$ (\$147) per $\mathrm{tCO}_{2}$ eq of abatement cost for 2030 to limit global warming to less than $2^{\circ} \mathrm{C}$ until 2100. Based on the above studies, two different levels of carbon tax scenario were developed as described in Table 3. $\$ 100 / \mathrm{tCO}_{2}$ eq by 2030 of carbon tax rate was assigned in a low tax scenario and $\$ 200 / \mathrm{tCO}_{2}$ eq by 2030 was assigned in a high carbon tax scenario. In the line with TIAM model's $5 \%$ of annual actualisation, we increased the carbon tax rate to $\$ 270 / \mathrm{tCO}_{2} \mathrm{eq}$ and $\$ 530 / \mathrm{tCO}_{2}$ eq until 2050 for each scenario using the same discount rate.

\section{Results}

The modelling results were analysed to compare the effects of national or international commitments to GHG mitigation and bioenergy targets in the four Asian countries, 
China, India, Japan and South Korea. Firstly, the analysis spotlights the evolution of GHG emissions through these different scenarios. We then studied the bioenergy consumption patterns in end uses. Lastly, we investigated the energy transition in the power supply sector with a focus on bioenergy. The results allowed us to discuss an effective path among different instruments to develop the bioenergy sector.

\subsection{INDCs' position in energy climate scenarios}

In this section, the GHG emission evolution of each climate scenario is studied with a focus on the GHG emission reduction targets announced in INDCs reports. Among the four studied countries, South Korea is the only one whose announced GHG target results in an emission level close to the 'global Factor2 $G H G$ ' scenario, in other words, in line with the objective of a $2^{\circ} \mathrm{C}$ maximum increase in global temperature. South Korea's GHG emissions are projected to rise to $0.45 \mathrm{GtCO}_{2}$ eq with its INDCs target by 2030, which is similar to estimated GHG emissions of $0.42 \mathrm{GtCO}_{2}$ eq under global GHG Factor2 scenario (Figure 2). However, note that South Korea's GHG INDC mitigation target is based on the BAU projection from a model other than TIAM-FR, i.e., the Korea Energy Economics Institute Energy and GHG Modeling System (KEEI-EGMS) (Republic of Korea, 2015). These two different models give different BAU projections for 2030, i.e., $0.85 \mathrm{GtCO}_{2}$ eq from KEEI-EGMS and $0.61 \mathrm{GtCO}_{2}$ eq from TIAM-FR. These different levels of BAU emissions thus derived different GHG emission limits. The estimated GHG emissions target of about $0.63 \mathrm{GtCO}_{2}$ eq, by applying the same GHG reduction rate, $25.7 \%$, to BAU projection from South Korea's model, already exceeds projected BAU emissions without any climate constraint from TIAM-FR. This observation proves that the current GHG emission target of South Korea, which is based on BAU emissions, is sensitive to various assumptions and to the behaviour of the projection model. Hence, the current type of GHG mitigation target may require more studies to provide a consistent contribution to global climate change actions.

Figure 2 GHG emission projection for South Korea until 2030

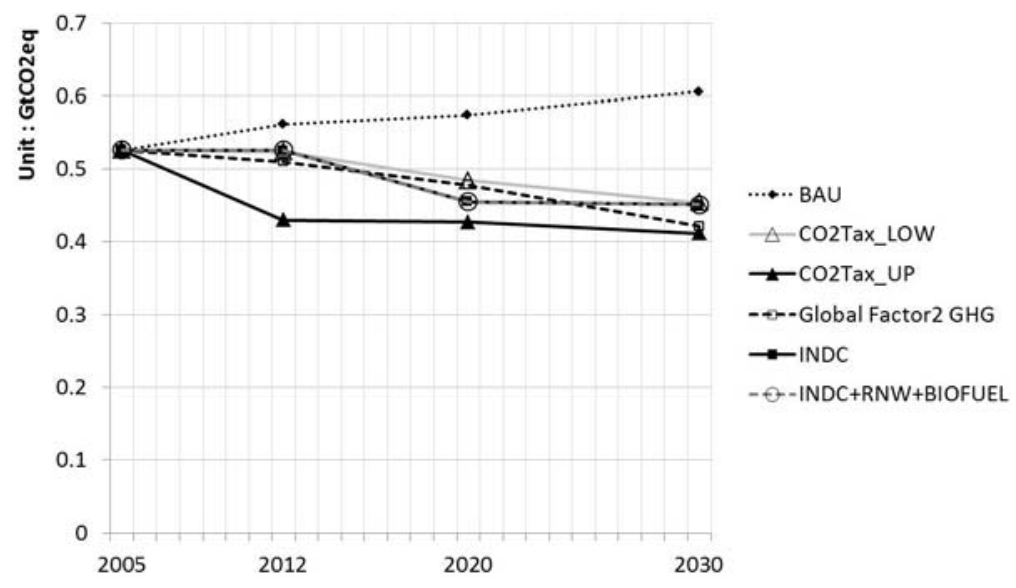


Hence, targets to reduce GHG emissions by 2030 in China, Japan and India derive GHG emissions that are a long way from global GHG emissions reduction target. In 2030, China's GHG emissions are estimated to increase to $9.5 \mathrm{GtCO}_{2} \mathrm{eq}$ with the INDCs target and achieve a $20 \%$ GHG emission reduction compared to BAU level.

Figure 3 GHG emission projection for China until 2030 (see online version for colours)

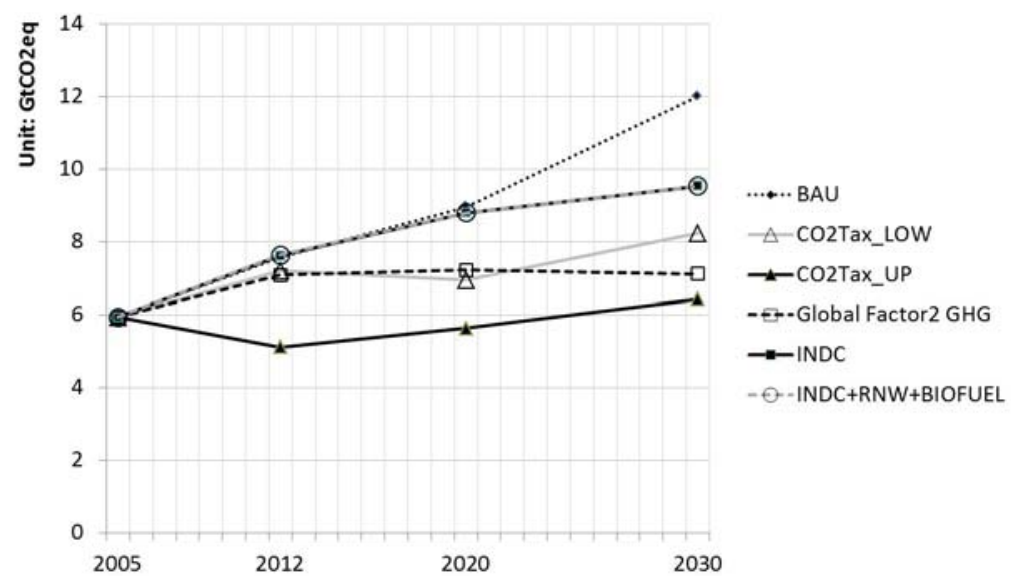

Nevertheless, the GHG emission level reached under the INDCs scenario is still a long way from fulfilling the global Factor $2 G H G$ scenario, which requires that emissions drop to a minimum of $7.1 \mathrm{GtCO}_{2} \mathrm{eq}$ (Figure 3).

Figure 4 GHG emission projection for Japan until 2030 (see online version for colours)

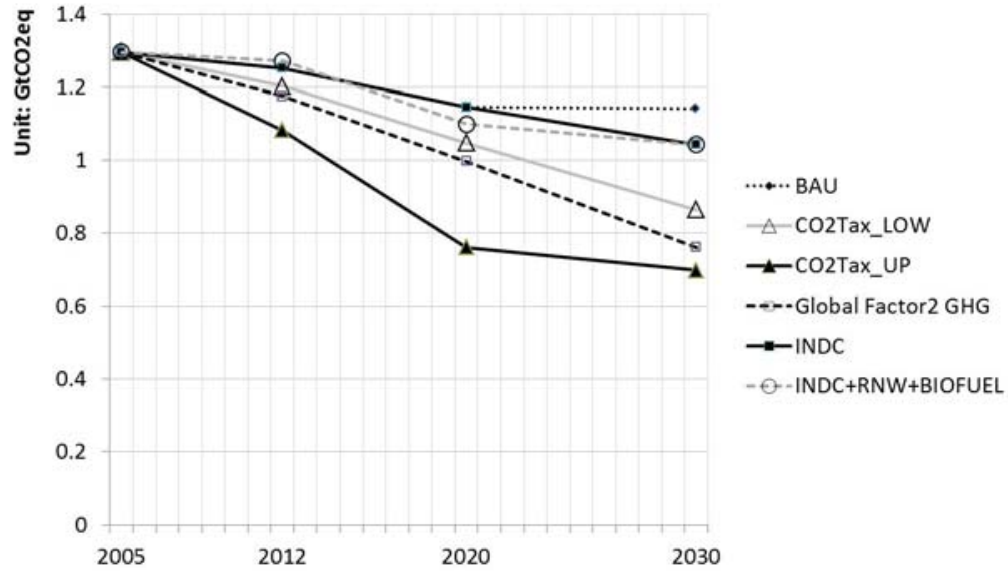

Regarding Japan, the INDC scenario is evaluated as the least ambitious of the scenarios. Japan's GHG emissions, with INDCs target of $1.04 \mathrm{GtCO}_{2} \mathrm{eq}$, exceed the global Factor2 scenario by about $37 \%$, at $0.75 \mathrm{GtCO}_{2} \mathrm{eq}$, and achieve only a $9 \%$ reduction compared to BAU level, $1.14 \mathrm{GtCO}_{2}$ eq (Figure 4). The graph of Japan's GHG emissions shows a gradual drop since 2007, due to its decreasing population and changes in industrial structure (Kang et al., 2015). Nevertheless, according to the model's results, the global 
Factor2 objective requires greater contribution from Japan, and its current INDCs target is judged to be insufficient.

This non-conformity with global Factor2 GHG scenario intensifies in India. India's current GHG intensity reduction pledge is too generous to pull down the GHG emissions from BAU level. The INDC scenario for India shows that GHG emissions increase up to $3.2 \mathrm{GtCO}_{2}$ eq by 2030 , which exceeds allowed GHG emissions by about $62 \%$ under global Factor2 GHG scenario (1.9 $\mathrm{GtCO}_{2}$ eq). And India achieves only $10 \%$ of GHG reduction from its BAU GHG emissions level, $3.6 \mathrm{GtCO}_{2} \mathrm{eq}$ (Figure 5).

Figure 5 GHG emission projection for India until 2030 (see online version for colours)

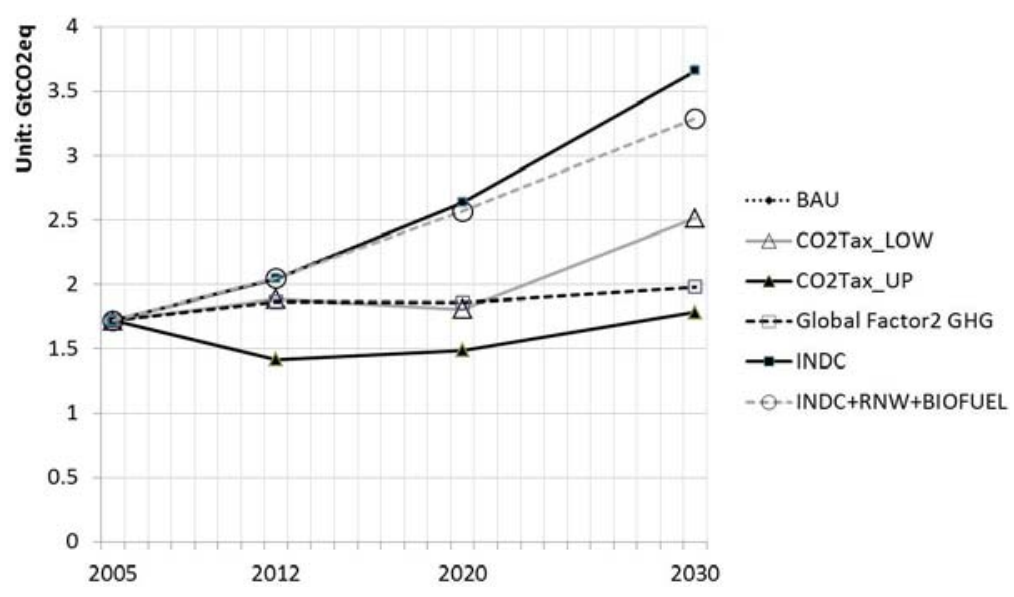

As observed above, none of the INDCs targets of the four studied countries is ambitious enough to reach the global Factor2 objective. Although South Korea's GHG emissions approach the global Factor2 target, it still needs to make further efforts to close the gap of about 0.3 Gt CO2eq. Furthermore, GHG emissions under the INDC scenario remain close to the BAU level. Among the scenarios, $\mathrm{CO}_{2}$ tax with $\$ 200 / \mathrm{tCO}_{2} \mathrm{eq}$ in 2030 requires the largest reduction of GHG emissions. Then, the GHG emissions of global Factor2 scenario always follow the $\mathrm{CO}_{2}$ tax_UP scenario. The $\mathrm{CO}_{2}$ tax_LOW scenario comes after the global Factor2 scenario. This result indicates that a carbon tax mechanism without direct emission targets can economically impose effective duties on China, India, Japan and South Korea to reduce global GHG emissions by $50 \%$ in 2100 . Moreover, we can conclude that the $\mathrm{CO}_{2}$ abatement cost to achieve a $50 \%$ reduction in global GHG emissions is between $100 \$$ and $200 \$$ in these countries.

\subsection{Bioenergy consumption patterns under climate constraints}

In this section, we analyse the bioenergy consumption changes in final energy consumption through different scenarios. The results show that the first choice to respond to climate constraints in these countries was transition from coal to gas and other less GHG-emitting energies. The energy transition to bioenergy then occurred with a higher climate constraint. In all four countries studied, the most restrictive climate scenario, which is a high level of $\mathrm{CO}_{2}$ tax, promoted more bioenergy consumption than the other 
scenarios. Bioenergy consumption then decreased in line with GHG emission target levels.

In the case of China, bioenergy consumption rises to $12.2 \mathrm{EJ}$ ( $22.9 \%$ of total final energy consumption) by 2030 with the high carbon tax scenario, although it remains at $5.5 \mathrm{EJ}(11.4 \%$ of total) with the BAU scenario. The INDC scenario brings up bioenergy consumption to $8.3 \mathrm{EJ}$ ( $8.1 \%$ of total), which rises to $8.4 \mathrm{EJ}$ when bound to renewable energy targets. On the contrary, coal consumption drops fast as a first reaction to climate-energy constraints and is replaced with gas (Figure 6). From the lowest level climate scenario (INDC) to the highest level $\left(\mathrm{CO}_{2}\right.$ tax_UP), coal consumption decreases to between $6.3 \mathrm{EJ}$ and $22.5 \mathrm{EJ}$ in comparison with 3.6 EJ under the BAU scenario by 2030.

Figure 6 Final energy consumption until 2030: China

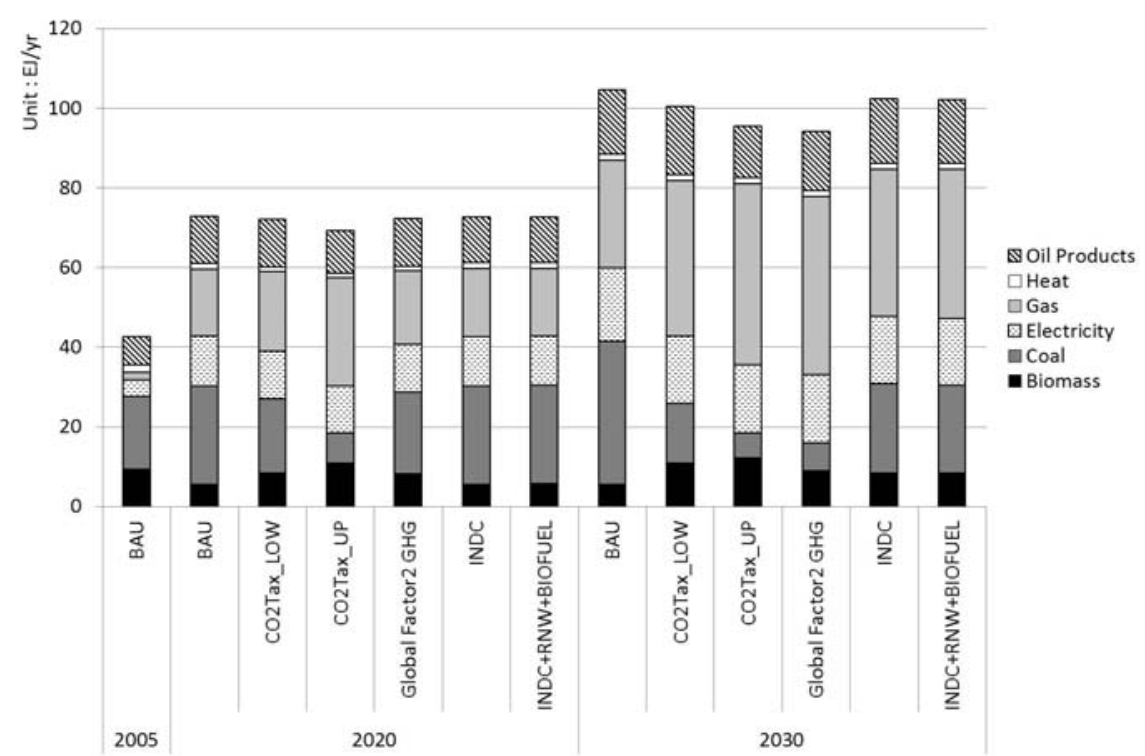

In terms of India's final energy consumption, biofuel consumption starts to appear in 2020 under the INDC scenario combined with a $20 \%$ biofuel blending mandate. However, India's voluntary GHG target does not sufficiently drive bioenergy consumption compared to the BAU scenario. For example, the INDC scenario derives about 6 EJ of bioenergy consumption in its total final energy consumption by 2020 as well as in the BAU scenario.

However, by strengthening climate constraints by 2030, bioenergy consumption becomes more significant under climate scenarios than in the BAU scenario. While the $B A U$ scenario shows bioenergy consumption of $7.1 \mathrm{EJ}$ (11\% in total), intensified climate scenarios push it to 11.2 EJ. In the case of fossil energy consumption, India's INDCs pledges still allow a significant quantity of coal consumption, about $30 \%$ of total final consumption, due to a low restriction on GHG emissions (Figure 7). 
Figure 7 Final energy consumption until 2030: India

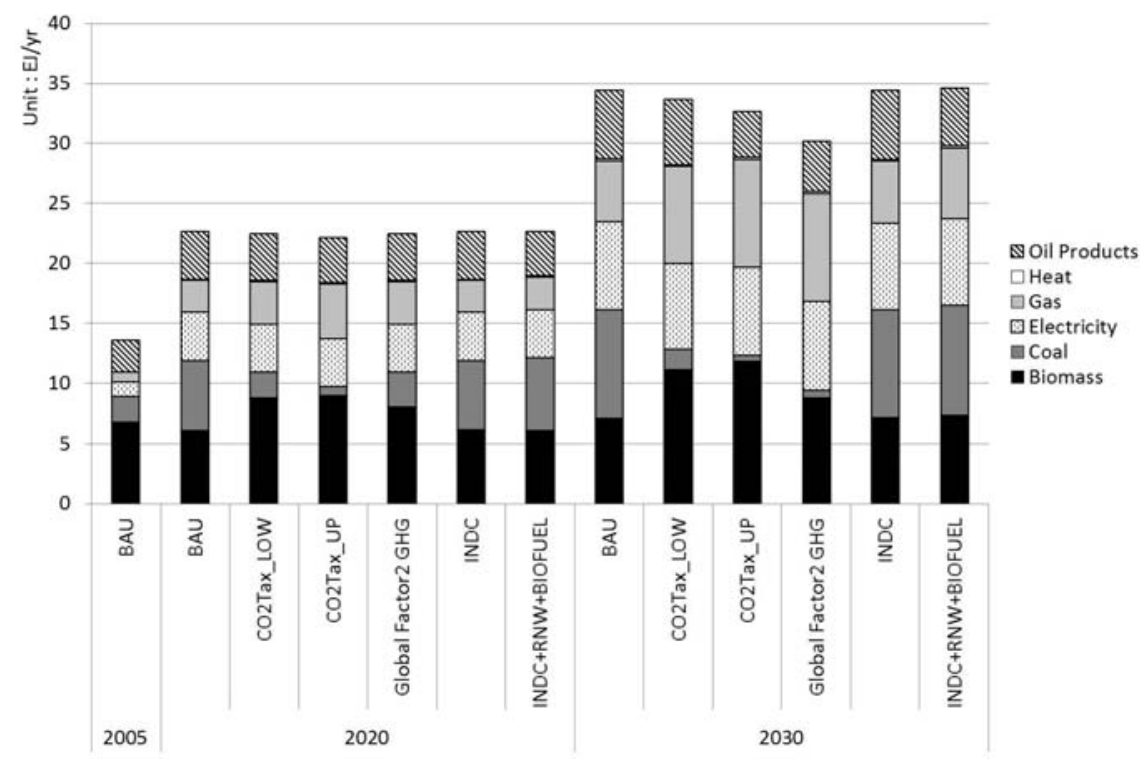

Figure 8 Final energy consumption until 2030: Japan

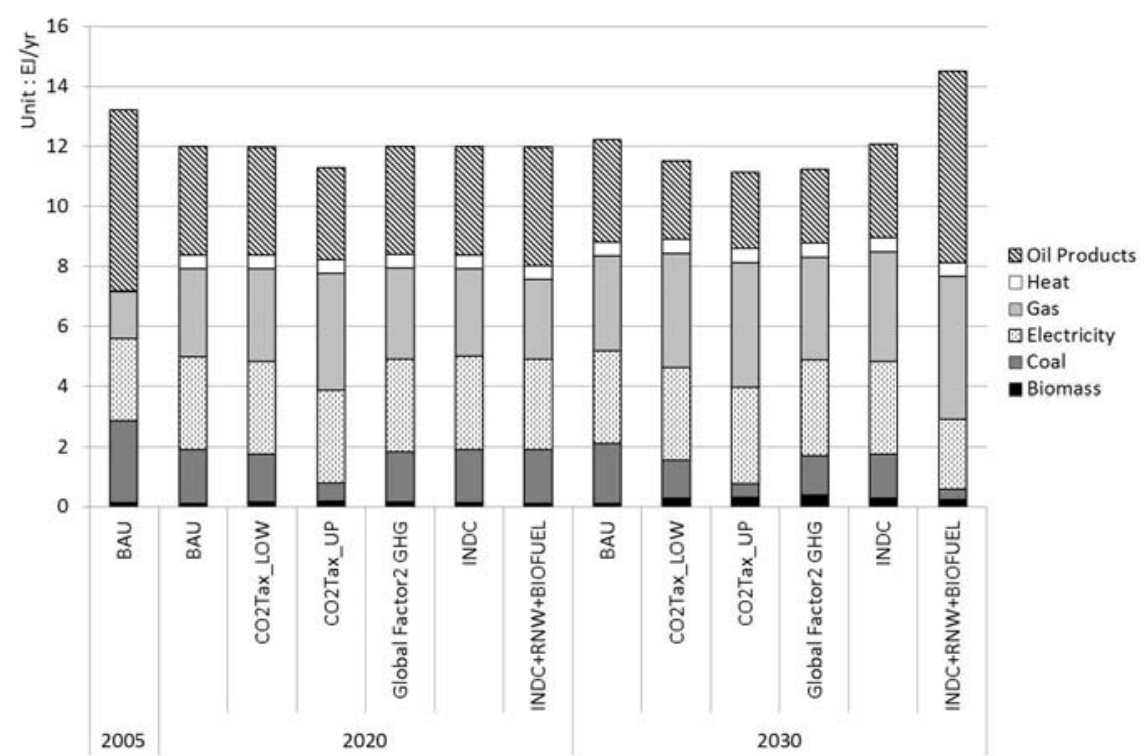


In Japan, bioenergy's share of final energy consumption is insignificant during all projected years, only representing between 1.6\% (0.24 EJ) and 3.3\% (0.37 EJ) (Figure 8). One reason why Japan's bioenergy consumption remains low is that Japan is the only country that has set a maximum blending rate of biofuels, as described in Section 2, due to vehicle performance and security issues. Hence, this regulation saturates the further promotion of biofuels in the transport sector. Another reason is that Japan's renewable energy target encourages the use of renewable energies other than biomass.

Regarding the result of the $I N D C+R N W+B I O$ scenario, bioenergy consumption in end uses is lower than in the INDC scenario due to the imposed minimum share of renewable energy in the power supply sector. Also, the renewable energy target accelerates the exit from coal consumption at a similar level of the highest climate constraint, $\mathrm{CO}_{2}$ tax $U P$.

However, the $I N D C+R N W+B I O$ scenario does not only limit coal consumption, it also increases the consumption of oil products, while the $\mathrm{CO}_{2}$ tax scenario limits both of them. This analysis implies that the current INDC scenario combined with a renewable energy target is only sufficient to reduce the share of coal, but not to reduce the entire fossil energy consumption or motivate bioenergy use in final consumption.

In South Korea, the change in the final energy consumption pattern is not dissimilar to Japan's situation. Bioenergy is also not the first promising option to reduce GHG emissions, and tighter climate scenarios push bioethanol and biodiesel consumption above the minimum blending rate from 2030. The share of biofuel in final energy consumption increases to $3 \%$ (alcohol $2.3 \%$ and biodiesel $0.7 \%$ ) by 2030 (Figure 9 ).

Figure 9 Final energy consumption until 2030: South Korea

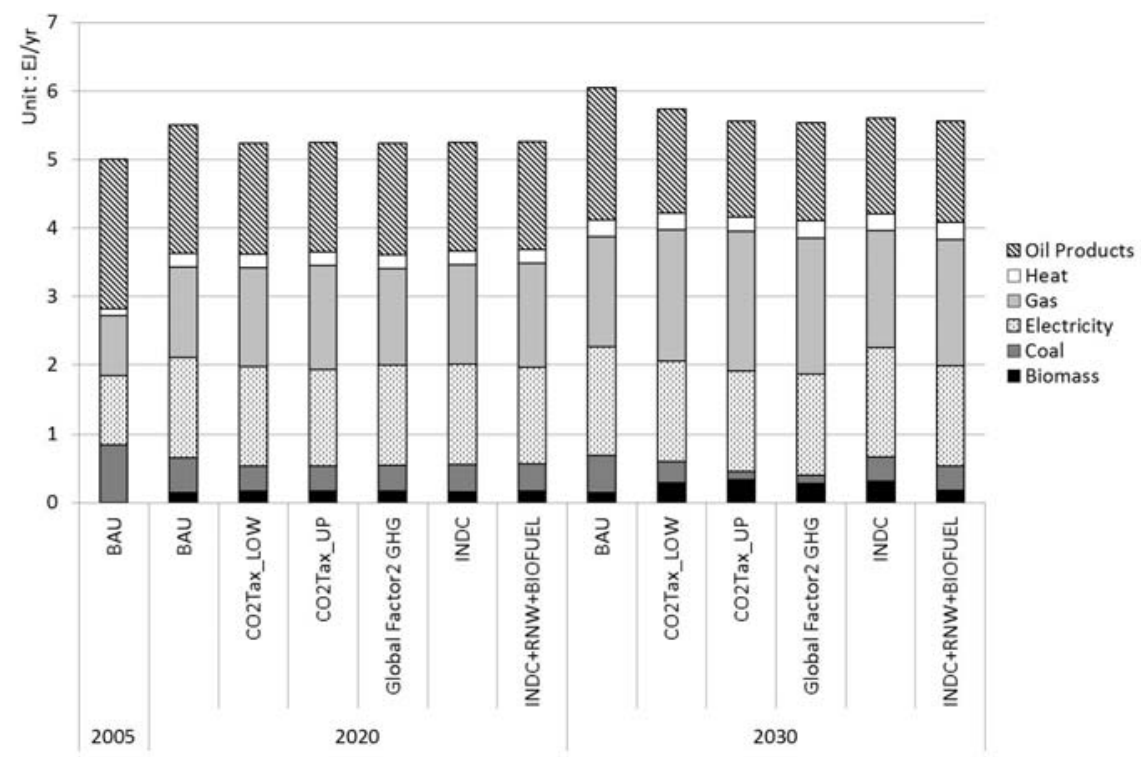


Figure 10 shows scenario results in the power supply sector from all types of energy with or without CCS technology and also $\mathrm{CH} 4$ options, which refer to electricity generation from $\mathrm{CH} 4$ abatement technologies, such as using leaked $\mathrm{CH} 4$ gases during storage and transmission, landfill gases, anaerobic digestion from manure, etc.

From the results, similarly to the change in final energy consumption, three phases of energy and technology transitions were identified. Firstly, the transition from coal to gas occurs no matter which level of climate constraint is applied. This phenomenon is commonly observed in all four studied countries. Secondly, the technology switch from coal to coal CCS technology occurs with stricter GHG emission limits. In the case of China, India and Japan, sufficiently restrictive climate scenarios, such as $\mathrm{CO}_{2}$ tax_LOW, global Factor $2 \mathrm{GHG}$, and $\mathrm{CO}_{2}$ tax_UP, increase coal CCS technology. In addition, the more restrictive the climate scenario, the more common the use of coal CCS technology. Lastly, gas CCS and biomass CCS technologies penetrate to further reduce GHG emissions in the power supply sector.

In addition, the results show the primary domination of coal CCS under a climate change scenario. With electricity generation under stronger climatic constraints, for example, $\mathrm{CO}_{2}$ tax_UP and global Factor2 GHG scenarios, coal CCS technology represents about $57 \%$ for China, $58 \%$ for India and $39 \%$ for Japan by 2030 . Meanwhile, coal CCS technology does not come up for South Korea, but only the first phase of energy transition from coal to gas occurs until 2030, and petroleum products still dominate the energy mix for power supply. However, the extended projection until 2050 with higher climate constraints leads to the development of gas CCS technology for South Korea by 2050.

In energy mix of the power supply sector, renewable energies and CCS technologies are in competition. We also observed that higher climate constraints increase the introduction of CCS technologies, while the share of bioenergy decreases; for example, bioenergy's share in the power supply drops to less than $0.03 \%$ for China, $5.8 \%$ for India, $1.23 \%$ for Japan, and $0 \%$ for South Korea. However, a direct target mechanism on bioenergy can maintain bioenergy's share in the energy mix for power supply. The scenario with renewable energy policies, INDC+RNW+BIOFUEL, produces $22 \%$ of electricity from biomass in India, 7.3\% in China, 5\% in Japan and 1.6\% in South Korea by 2030 . Based on these observations, it can be concluded that GHG mitigation policies should be paired with direct target mechanism on bioenergy use.

Table 5 Total power supply by 2030 (unit: EJ)

\begin{tabular}{lcccc}
\hline Power supply by 2030 (EJ) & China & India & Japan & South Korea \\
\hline BAU & 6.69 & 2.46 & 1.06 & 0.51 \\
CO2Tax_LOW & 5.99 & 2.43 & 1.06 & 0.47 \\
CO2Tax_UP & 6.12 & 2.53 & 1.10 & 0.47 \\
Global Factor2 GHG & 6.06 & 2.48 & 1.09 & 0.47 \\
INDC & 5.97 & 2.43 & 1.06 & 0.51 \\
INDC+RNW+BIOFUEL & 5.98 & 2.39 & 0.80 & 0.47 \\
\hline
\end{tabular}


Figure 10 Energy mix for power supply in China, India, Japan and South Korea by 2030

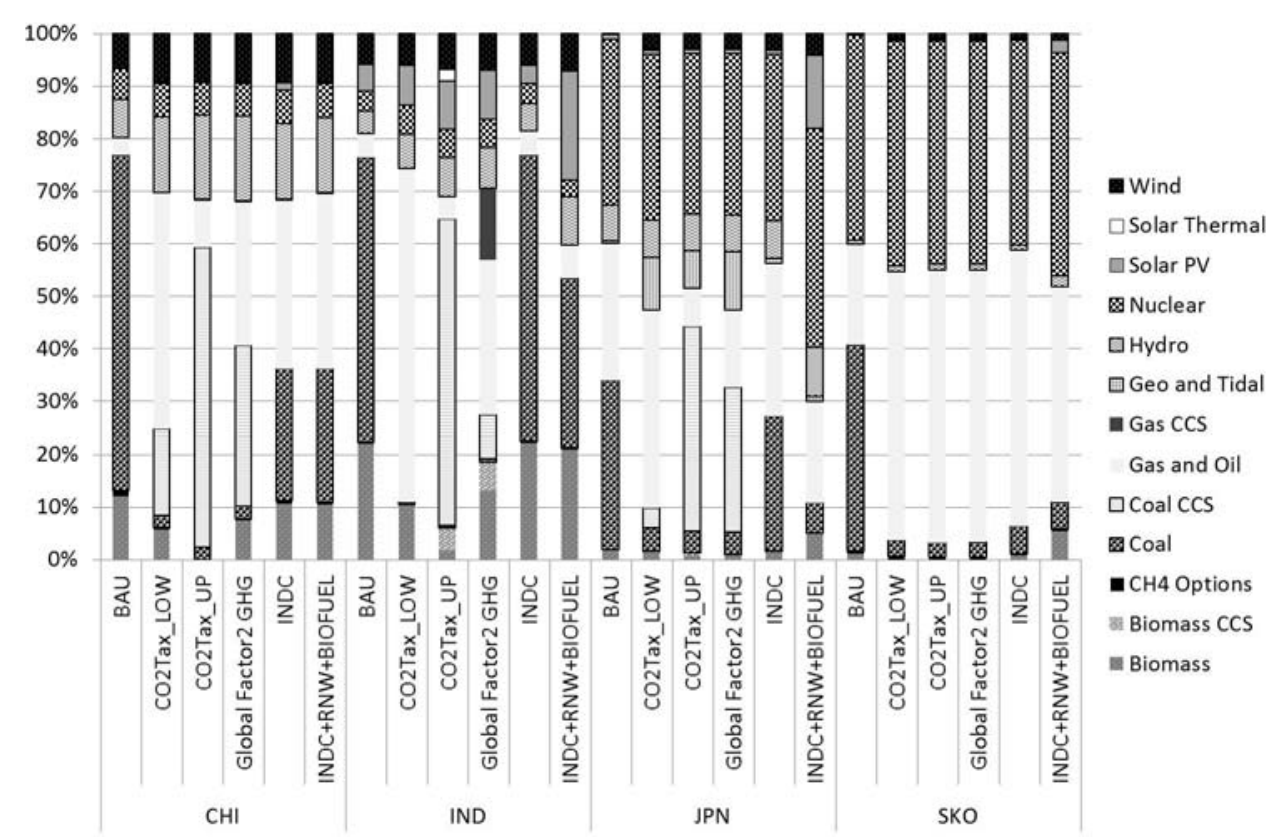

Figure 11 Energy mix in the transport sector in China, India, Japan, and South Korea by 2030

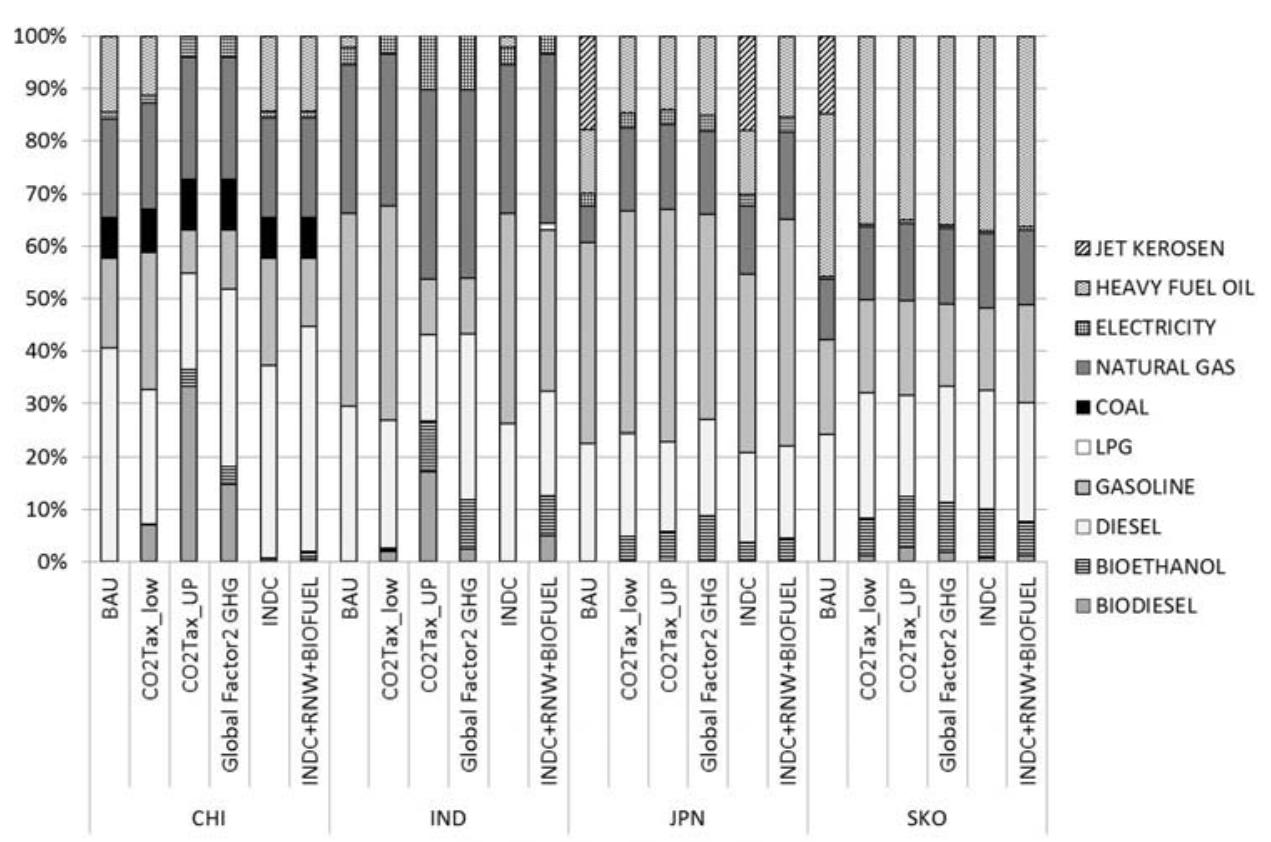




\subsection{Transport sector}

The scenario results show that biofuel immediately replaces conventional fossil fuels such as gasoline and diesel under all climate scenarios in the four countries studied and that the share of biofuel increases with the level of climate constraint. Nevertheless, current INDCs GHG emission targets are evaluated as too lax to promote biofuel in the transport sector. For example, in India, biodiesel consumption remains less than $0.1 \%$ of diesel consumption under the INDC only scenario (Figure 11).

On the other hand, INDC with a mandate biofuel blending rate effectively raised the targeted biofuel consumption. Table 6 shows a comparison between the INDC scenario and INDC combined with renewable and bioenergy targets.

In the case of China, India, and South Korea, biofuel policy promotes biofuel consumption even more than a minimum blending rate of $10 \%$ bioethanol in China, $20 \%$ bioethanol and biodiesel in India, and 5\% biodiesel in South Korea. As the Japanese government has applied a maximum biofuel blending rate for security reasons, bioethanol blending drops to $10 \%$ under the INDC+RNW+BIOFUEL scenario compared to $11 \%$ under the $I N D C$ scenario.

Table 6 Biofuel consumption in the transport sector by 2030 in PJ (blending rate in \%)

\begin{tabular}{lcccc}
\hline Country & $I N D C$ & $I N D C+R N W+$ BIOFUEL & Policy & Fuel type \\
\hline China & $28(1 \%)$ & $161(11 \%)$ & $10 \%$ min. & Bioethanol \\
India & $0(0 \%)$ & $285(25 \%)$ & $20 \%$ min. & Bioethanol \\
& $<0.1(0.003 \%)$ & $114(25 \%)$ & $20 \%$ min. & Biodiesel \\
\multirow{2}{*}{ Japan } & $103.83(11 \%)$ & $99.49(10 \%)$ & $10 \%$ max. & Bioethanol \\
& $0(0 \%)$ & $0.15(0.04 \%)$ & $5 \%$ max. & Biodiesel \\
South Korea & $7.93(3 \%)$ & $16.19(5.2 \%)$ & $5 \%$ min. & Biodiesel \\
\hline
\end{tabular}

\section{Perspectives and conclusions}

The scenario analysis shows that bioenergy is not the first choice to reduce GHG emissions except for the transport sector. Based on the scenario results, biofuel immediately penetrates and replaces fossil fuels in the transport sector under any climate scenario. In addition, the share of biofuel in total energy consumption in the transport sector remains significant until the end of the time horizon, although new clean energy sources, such as electricity, emerge with a more restrictive climate constraint. Despite the priority of biofuel under climate constraints, current GHG pledges in INDCs are not ambitious enough to lead to biofuel consumption in the transport sector. However, under the INDC+RNW+BIOFUEL scenario, the share of renewable energy including bioenergy increases in primary energy from $47 \%$ to $50 \%$ for China, $39 \%$ to $46 \%$ for India, $30 \%$ to $44 \%$ for Japan, and $46 \%$ to $48 \%$ for South Korea. As observed above, the imposition of a direct target on bioenergy use, along with climate constraint, is identified as an efficient instrument to promote bioenergy.

In addition, it should be noted that GHG mitigation is not the only driving force to develop bioenergy. Yan and Lin (2009), Kang et al. (2015) and Zhou and Thomson (2009) have identified different driving forces for bioenergy development in Asian 
countries. Apart from the climate change issue, energy security, public health, new trading markets, job creation and rural development are the key driving forces for bioenergy in these countries. Specifically, the insufficient fossil energy resources in Asia have led this region to diversify the energy mix with other new energy sources, including bioenergy. For example, insufficient energy access in India and China has resulted in significant development of family-scale biogas plants. In addition, Japan promotes bioenergy use for power supply to decrease its high dependency on nuclear energy.

In developing countries such as China and India, households still largely depend on traditional biomass for cooking and heating. This consumption pattern is expected to change little in the near future because culture and traditions play a significant role in household energy consumption in addition to energy access (van der Kroon et al., 2013).

Thus, many different factors can impact on developing bioenergy with a target of reducing GHG emissions. Furthermore, environmental efficiency and cost effectiveness analyses comparing different types of bioenergy should be carried out prior to promoting bioenergy. Based on a literature review (Gerssen-Gondelach et al., 2014; Greene et al., 2004; Hennig and Gawor, 2012; Cherubini and Strømman, 2011), the use of biomass for power and heat generation showed better environmental and economic performance than biofuels in transport, especially, in the case of first-generation biofuel.

On the other hand, bioenergy development in these countries can face different barriers. Firstly, bioenergy can compete with food security. In China and India, using edible crops to produce biofuel has provoked price volatility on grains and thus threatened food self-sufficiency. Secondly, deforestation resulting from the use of forestry biomass can have serious impacts on biodiversity and reduce soil carbon stocks. Indirect GHG emissions from changes in land use and deforestation need to be evaluated when promoting bioenergy. Lastly, immature technology on bioenergy conversion and end-use equipment requires more investments to secure economic viability and usability. These issues could be critical for bioenergy promotion and need to be addressed along with GHG mitigation and bioenergy policies.

In this study, different pathways of $\mathrm{CO}_{2}$ emission mitigation targets are analysed with a focus on bioenergy deployment. In terms of GHG emissions, the Paris Agreement at COP 21 invited all countries to contribute to maintaining global warming below $2^{\circ} \mathrm{C}$ for 2100. Despite successful awareness-raising of the necessity for GHG mitigation, the announced pledges to reduce GHG emissions in the form of INDCs are far from sufficient to achieve global GHG mitigation.

Regarding bioenergy deployment, bioenergy consumption increases with different climate constraints. However, current INDCs GHG emission pledges are not sufficient to drive bioenergy development unless accompanied by specific bioenergy targets. Also, we identified that CCS technology becomes dominant from a certain level of climate constraint. In the case of power supply, the share of bioenergy decreases in the total energy mix with the transition to more economic and less GHG emitting technologies like Coal and Gas CCS technologies. Consequently, the results show that higher climate constraints do not always guarantee more bioenergy development.

Hence, for the purpose of GHG mitigation, bioenergy is evaluated as a less interesting choice than CCS technology and other renewable energies. To promote bioenergy, GHG mitigation targets need to be paired with specific bioenergy policies. Also, investments in bioenergy technology and the maturation of the global bioenergy market are necessary to boost the economic viability and affordability of bioenergy. 


\section{Acknowledgements}

This research was supported by the Chair Modeling for sustainable development, driven by MINES ParisTech, Ecole des Ponts ParisTech, and AgroParisTech, supported by ADEME, EDF, GRTgaz, SCHNEIDER ELECTRIC and the French Ministry of Ecology, Sustainable Development and Energy.

\section{References}

Biberacher, M. and Gadocha, S. (2012) Final Report - Global Energy Scenarios Analysis.

Cherubini, F. and Strømman, A.H. (2011) 'Life cycle assessment of bioenergy systems: state of the art and future challenges', Bioresour. Technol., Vol. 102, No. 2, pp.437-451.

China (2015) Intended Nationally Determined Contribution (INDC) - China, UNFCCC.

Choi, H. (2015) Korea Confirmed 2030 Greenhouse Gas Reduction Target of 37\% Reduction as Compared to BAU (851 Million Tons), Minist. Enviornment, Repub. Korea.

den Elzen, M.G.J., Hof, A.F., Beltran, A.M., Grassi, G., Roelfsema, M., van Ruijven, B., van Vliet, J. and van Vuuren, D.P. (2010) 'The Copenhagen Accord: abatement costs and carbon prices resulting from the submissions', Environ. Sci. Policy, Vol. 14, No. 1, pp.28-39.

den Elzen, M.G.J., Hof, A.F. and Roelfsema, M. (2011) 'The emissions gap between the Copenhagen pledges and the $2{ }^{\circ} \mathrm{C}$ climate goal: options for closing and risks that could widen the gap', Glob. Environ. Chang., Vol. 21, No. 2, pp.733-743.

Gerssen-Gondelach, S., Saygin, D., Wicke, B. and Faaij, A. (2014) 'Competing uses of biomass assessment and comparison of the performance of bio-based heat, power, fuels and materials', Renew. Sustain. Energy Rev., December, Vol. 40, pp.964-998.

Greene, N., Celik, F.E., Dale, B.E., Jackson, M., Jayawardhana, K., Jin, H., Larson, E.D., Laser, M.S., Lynd, L.R., MacKenzie, D., Mark, J., McBride, J., McLaughlin, S. and Saccardi, D. (2004) Growing Energy: How Biofuels Can Help End America's Oil Dependence, Natural Resources Defense Council report.

Hennig, C. and Gawor, M. (2012) 'Bioenergy production and use: comparative analysis of the economic and environmental effects', Energy Convers. Manag., Vol. 63, pp.130-137.

Iijima, M. (2014) Biofuels Annual: Japan Focuses on Next Generation Biofuels, USDA GAIN report.

India (2015) Intended Nationally Determined Contribution (INDC) - India, pp.1-38, UNFCCC.

International Energy Agency (IEA) (2013) Extended World Energy Balances, IEA World Energy Statistics and Balances database [online] http://www.oecd-ilibrary.org/energy/data/iea-worldenergy-statistics-and-balances/extended-world-energy-balances_data-00513-en (accessed 16 October 2015).

IPCC (2007) 'Summary for policymakers', in Solomon, S., Qin, D., Manning, M., Chen, Z. and Marqu, M. (Eds.): Phys. Sci. Basis, pp.7-22, Contrib. Work. Gr. I to Fourth Assess. Rep. Intergov. Panel Clim. Chang.

IPCC (2014) 'Summary for policymakers', in Pachauri, R.K. and Meyer, L.A. (Eds.): Climate Change 2014: Synthesis Report, p.151, Contribution of Working Groups I, II and III to the Fifth Assessment Report of the Intergovernmental Panel on Climate Change, IPCC, Geneva, Switzerland.

Japan (2015) Intended Nationally Determined Contribution (INDC) - Japan, UNFCCC.

Jian-Kun, H.E. (2015) 'China's INDC and non-fossil energy development', Adv. Clim. Chang. Res., Vol. 6, Nos. 3-4, pp.210-215.

Kang, S., Selosse, S. and Maïzi, N. (2015) 'Strategy of bioenergy development in the largest energy consumers of Asia (China, India, Japan and South Korea)', Energy Strateg. Rev., July, Vol. 8, pp.56-65. 
Korea Energy Agency (2015a) RFS Korea [online] http://www.energy.or.kr/renew_eng/ new/rfs.aspx (accessed 16 October 2015).

Korea Energy Agency (2015b) Program for Promoting NRE Deployment [online] http://www.kemco.or.kr/new_eng/pg02/pg02040705.asp (accessed 16 October 2015).

Labriet, M., Loulou, R. and Kanodia, A. (2008) The ETSAP-TIMES Integrated Assessment Model, IEA-ETSAP, Semi Annual ETSAP Regular Workshop, Paris.

Loulou, R. (2007) The TIMES Integrated Assessment Model (TIAM ): Some Details on Model and Database, IEA-ETSAP, TIAM day, Ottawa.

Loulou, R., Remme, U., Kanudia, A., Lehtila, A. and Goldstein, G. (2005a) Documentation for the TIMES Model Part I, pp.1-78, Energy Technology Systems Analysis Programme (ETSAP) [online] http://iea-etsap.org/index.php/documentation (accessed 3 May 2016).

Loulou, R., Remme, U., Kanudia, A., Lehtila, A. and Goldstein, G. (2005b) Documentation for the TIMES Model Part II, Energy Technology Systems Analysis Programme (ETSAP) [online] http://iea-etsap.org/index.php/documentation (accessed 3 May 2016).

McKinsey \& Company (2010) Impact of the Financial Crisis on Carbon Economics, pp.1-14, Mckinsey \& Company [online] http://www.mckinsey.com/business-functions/sustainabilityand-resource-productivity/our-insights/impact-of-the-financial-crisis-on-carbon-economicsversion-21 (accessed 30 April 2016).

Republic of Korea (2015) Intended Nationally Determined Contribution (INDC) - Republic of Korea, pp.1-4, UNFCCC.

Selosse, S., Assoumou, E., Maïzi, N. and Mazauric, V. (2010) 'Post-Kyoto policy implications on the energy system: a TIAM-FR long-term planning exercise', XXIe World Energy Congress, Montreal, Canada.

Selosse, S. and Garcia, N. (2014) CCS Development for a Low Carbon Future. Chaire Modélisation prospective au service du développement Durable, p.15, Les Cahiers de la Chaire, Sophia Antipolis, France.

Selosse, S. and Maizi, N. (2014) 'A regional perspective to achieve the future climate regime: a long-term analysis with the TIAM-FR model', International Conference on Economic Modeling.

UNFCCC (2015) COP21: Adoption of the Paris Agreement, Paris, France.

van der Kroon, B., Brouwer, R. and van Beukering, P.J.H. (2013) 'The energy ladder: theoretical myth or empirical truth? Results from a meta-analysis', Renew. Sustain. Energy Rev., April, Vol. 20, pp.504-513.

van Vliet, J., van den Berg, M., Schaeffer, M., van Vuuren, D.P., den Elzen, M., Hof, A.F., Beltran, A.M. and Meinshausen, M. (2012) 'Copenhagen Accord pledges imply higher costs for staying below $2^{\circ} \mathrm{C}$ warming', Clim. Change, Vol. 113, No. 2, pp.551-561.

Van Vuuren, D.P., Stehfest, E., den Elzen, M.G.J., van Vliet, J. and Isaac, M. (2010) 'Exploring IMAGE model scenarios that keep greenhouse gas radiative forcing below $3 \mathrm{~W} / \mathrm{m}^{2}$ in 2100 ', Energy Econ., Vol. 32, No. 5, pp.1105-1120.

Yan, J. and Lin, T. (2009) 'Biofuels in Asia', Appl. Energy, Vol. 86, No. s1, pp.1-10.

Zhou, A. and Thomson, E. (2009) 'The development of biofuels in Asia', Appl. Energy, Vol. 86, No. s1, pp.S11-S20. 


\section{Annexe 1}

GDP growth applied in TIAM-FR model from 2005 to 2050

\begin{tabular}{lccccccccccc}
\hline Region & Driver & 2005 & 2010 & 2015 & 2020 & 2025 & 2030 & 2035 & 2040 & 2045 & 2050 \\
\hline AUS & GDP & 1 & 1.15 & 1.29 & 1.45 & 1.58 & 1.71 & 1.8 & 1.91 & 2 & 2.12 \\
CAN & GDP & 1 & 1.15 & 1.28 & 1.43 & 1.49 & 1.56 & 1.62 & 1.69 & 1.75 & 1.83 \\
CHI & GDP & 1 & 1.58 & 2.16 & 2.92 & 3.79 & 4.97 & 6.19 & 7.53 & 9.28 & 11.13 \\
CSA & GDP & 1 & 1.23 & 1.48 & 1.76 & 2.05 & 2.37 & 2.73 & 3.17 & 3.72 & 4.33 \\
WEU & GDP & 1 & 1.15 & 1.28 & 1.42 & 1.57 & 1.73 & 1.82 & 1.95 & 2.06 & 2.21 \\
IND & GDP & 1 & 1.51 & 2.22 & 3.29 & 4.59 & 6.4 & 8.6 & 10.41 & 12.77 & 15.23 \\
JPN & GDP & 1 & 1.12 & 1.2 & 1.29 & 1.32 & 1.35 & 1.38 & 1.43 & 1.49 & 1.56 \\
MEA & GDP & 1 & 1.3 & 1.6 & 1.94 & 2.29 & 2.67 & 3.07 & 3.55 & 4.07 & 4.65 \\
MEX & GDP & 1 & 1.21 & 1.51 & 1.85 & 2.24 & 2.67 & 3.15 & 3.73 & 4.4 & 5.14 \\
ODA & GDP & 1 & 1.26 & 1.55 & 1.87 & 2.19 & 2.53 & 2.87 & 3.27 & 3.7 & 4.17 \\
EEU & GDP & 1 & 1.17 & 1.2 & 1.22 & 1.25 & 1.27 & 1.31 & 1.35 & 1.44 & 1.48 \\
FSU & GDP & 1 & 1.33 & 1.8 & 2.26 & 3.05 & 3.84 & 4.32 & 4.86 & 5.44 & 6.07 \\
SKO & GDP & 1 & 1.17 & 1.32 & 1.49 & 1.6 & 1.72 & 1.82 & 1.95 & 2.09 & 2.24 \\
USA & GDP & 1 & 1.19 & 1.39 & 1.61 & 1.82 & 2.03 & 2.19 & 2.36 & 2.5 & 2.67 \\
\hline
\end{tabular}

\section{Annexe 2}

Population growth applied in TIAM-FR model from 2005 to 2050

\begin{tabular}{lccccccccccc}
\hline Region & Driver & 2005 & 2010 & 2015 & 2020 & 2025 & 2030 & 2035 & 2040 & 2045 & 2050 \\
\hline AFR & POP & 1 & 1.12 & 1.24 & 1.37 & 1.49 & 1.62 & 1.74 & 1.85 & 1.95 & 2.04 \\
AUS & POP & 1 & 1.05 & 1.09 & 1.14 & 1.18 & 1.21 & 1.22 & 1.22 & 1.21 & 1.20 \\
CAN & POP & 1 & 1.04 & 1.08 & 1.12 & 1.16 & 1.18 & 1.19 & 1.19 & 1.18 & 1.17 \\
CHI & POP & 1 & 1.04 & 1.07 & 1.1 & 1.12 & 1.14 & 1.16 & 1.18 & 1.17 & 1.17 \\
CSA & POP & 1 & 1.07 & 1.14 & 1.21 & 1.27 & 1.33 & 1.4 & 1.47 & 1.55 & 1.62 \\
WEU & POP & 1 & 1.01 & 1.02 & 1.02 & 1.02 & 1.01 & 1.01 & 1.00 & 0.99 & 0.98 \\
IND & POP & 1 & 1.08 & 1.15 & 1.22 & 1.28 & 1.34 & 1.38 & 1.41 & 1.44 & 1.46 \\
JPN & POP & 1 & 1.01 & 1.01 & 1 & 0.99 & 0.98 & 0.97 & 0.95 & 0.94 & 0.94 \\
MEA & POP & 1 & 1.11 & 1.22 & 1.33 & 1.44 & 1.55 & 1.65 & 1.75 & 1.84 & 1.93 \\
MEX & POP & 1 & 1.07 & 1.14 & 1.2 & 1.25 & 1.31 & 1.37 & 1.44 & 1.52 & 1.59 \\
ODA & POP & 1 & 1.06 & 1.11 & 1.16 & 1.2 & 1.25 & 1.28 & 1.30 & 1.33 & 1.35 \\
EEU & POP & 1 & 0.97 & 0.95 & 0.92 & 0.89 & 0.86 & 0.83 & 0.80 & 0.78 & 0.75 \\
FSU & POP & 1 & 0.97 & 0.95 & 0.92 & 0.89 & 0.86 & 0.83 & 0.80 & 0.78 & 0.75 \\
SKO & POP & 1 & 1.06 & 1.11 & 1.16 & 1.2 & 1.25 & 1.28 & 1.30 & 1.33 & 1.35 \\
USA & POP & 1 & 1.05 & 1.1 & 1.15 & 1.21 & 1.25 & 1.26 & 1.26 & 1.25 & 1.24 \\
\hline
\end{tabular}




\section{Annexe 3}

Scenario results for final energy consumption (China, India, Japan and South Korea)

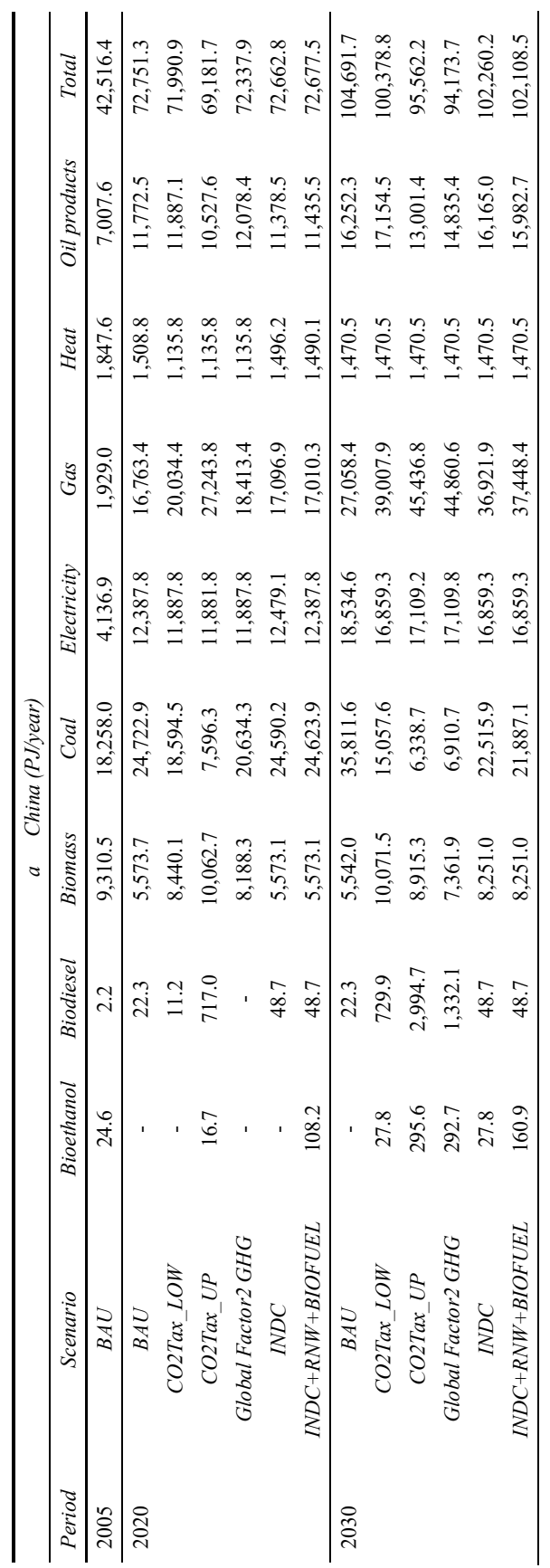


Scenario results for final energy consumption (China, India, Japan and South Korea) (continued)

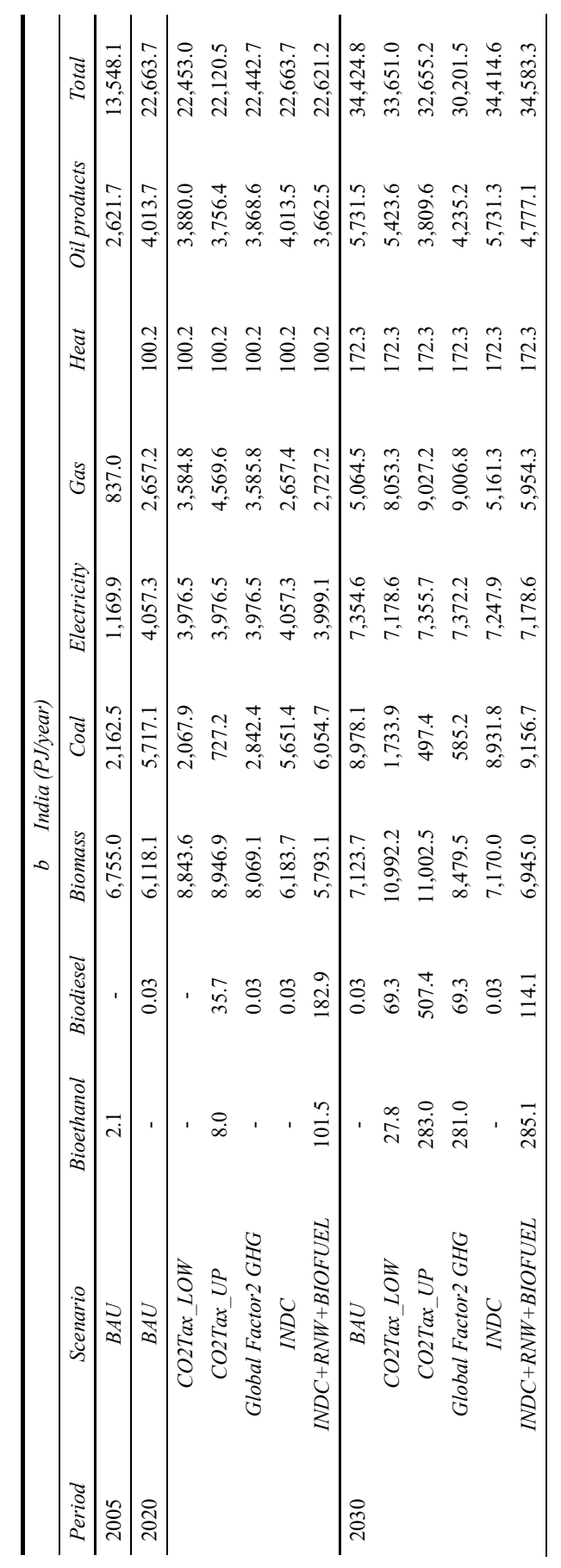


Scenario results for final energy consumption (China, India, Japan and South Korea) (continued)

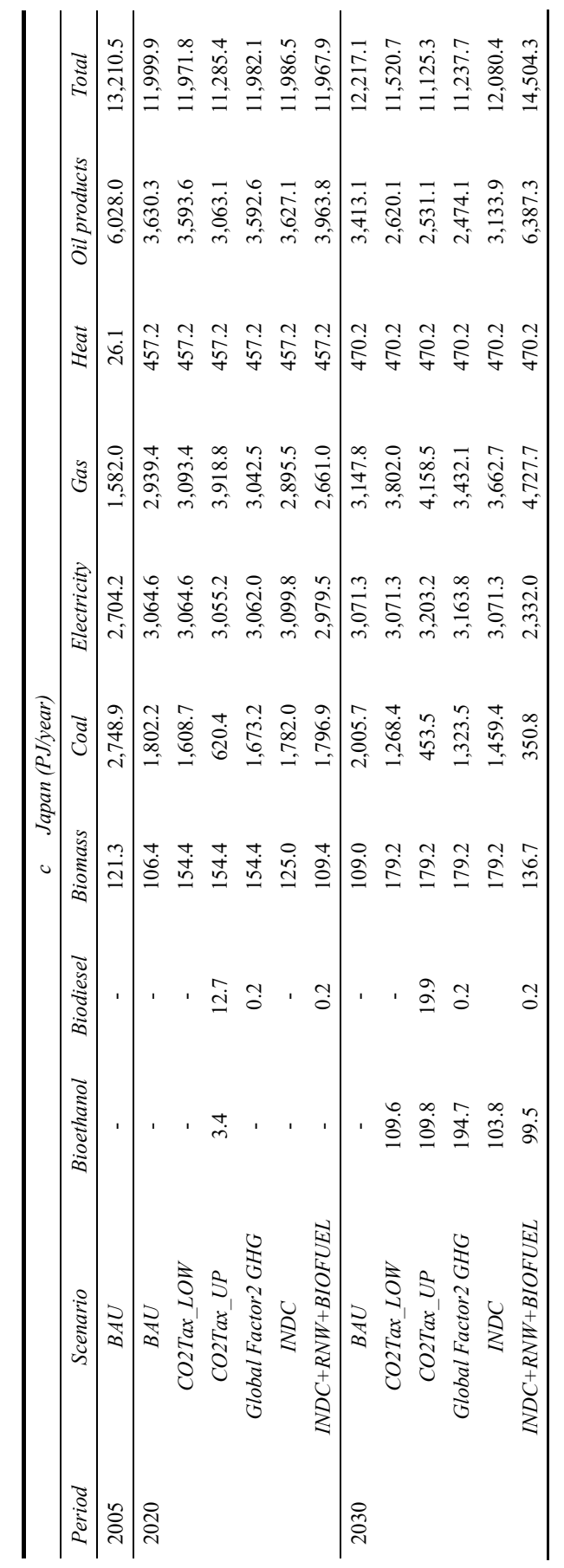


Scenario results for final energy consumption (China, India, Japan and South Korea) (continued)

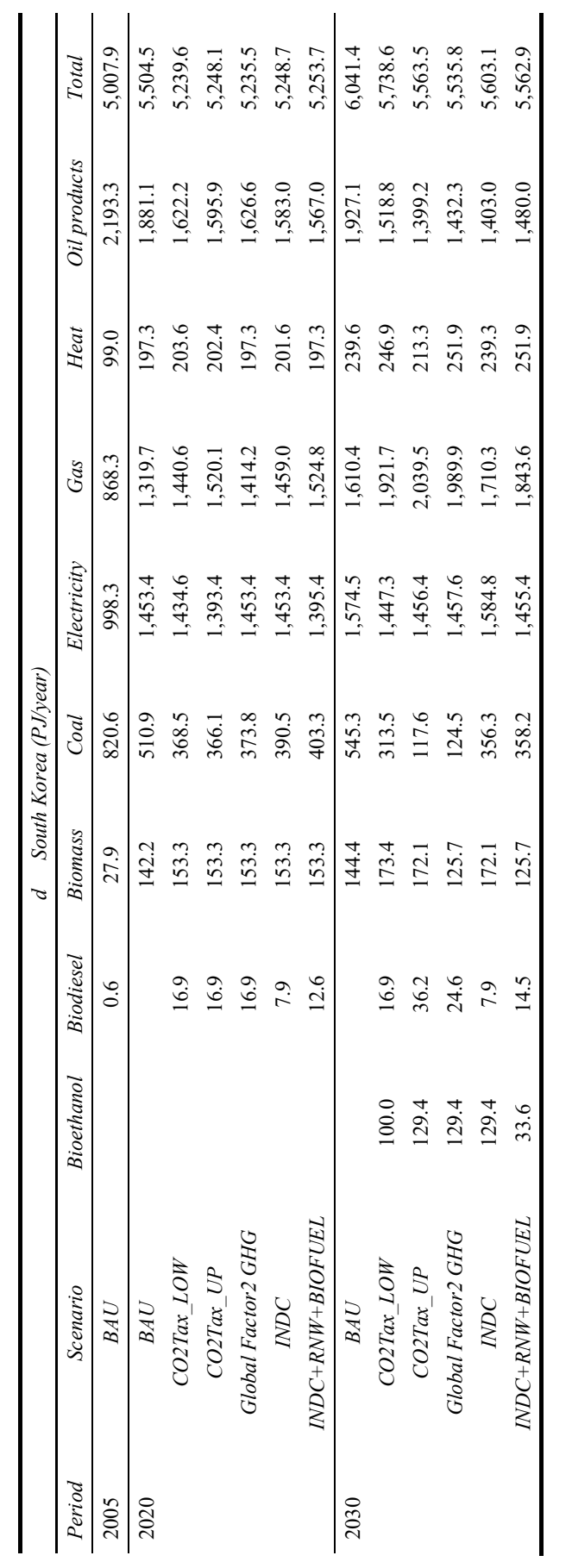




\section{Annexe 4}

Scenario results on power supply sector by 2030 (unit: PJ/year)

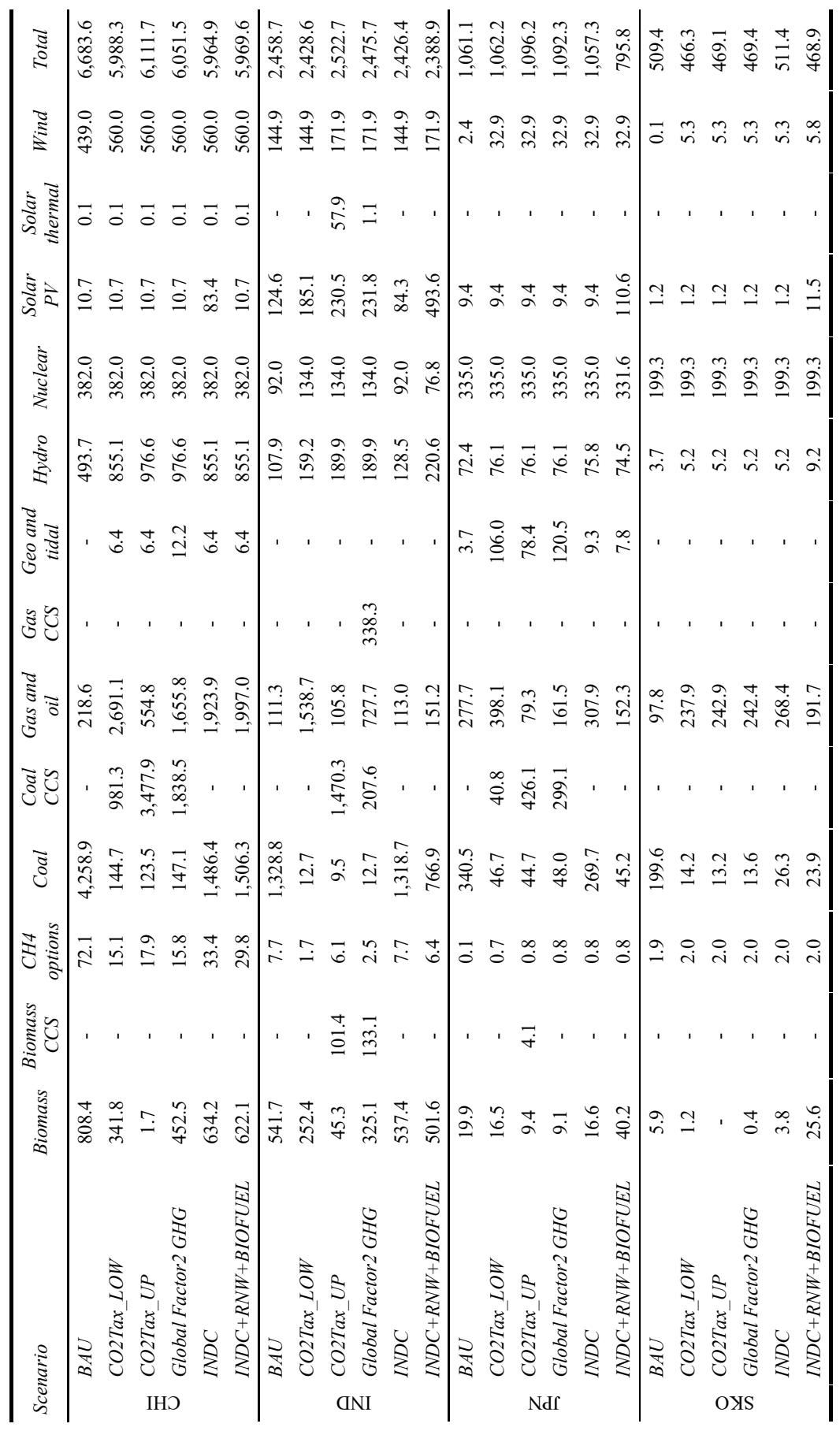




\section{Annexe 5}

Final energy consumption in transport sector by 2030 (unit: PJ/year)

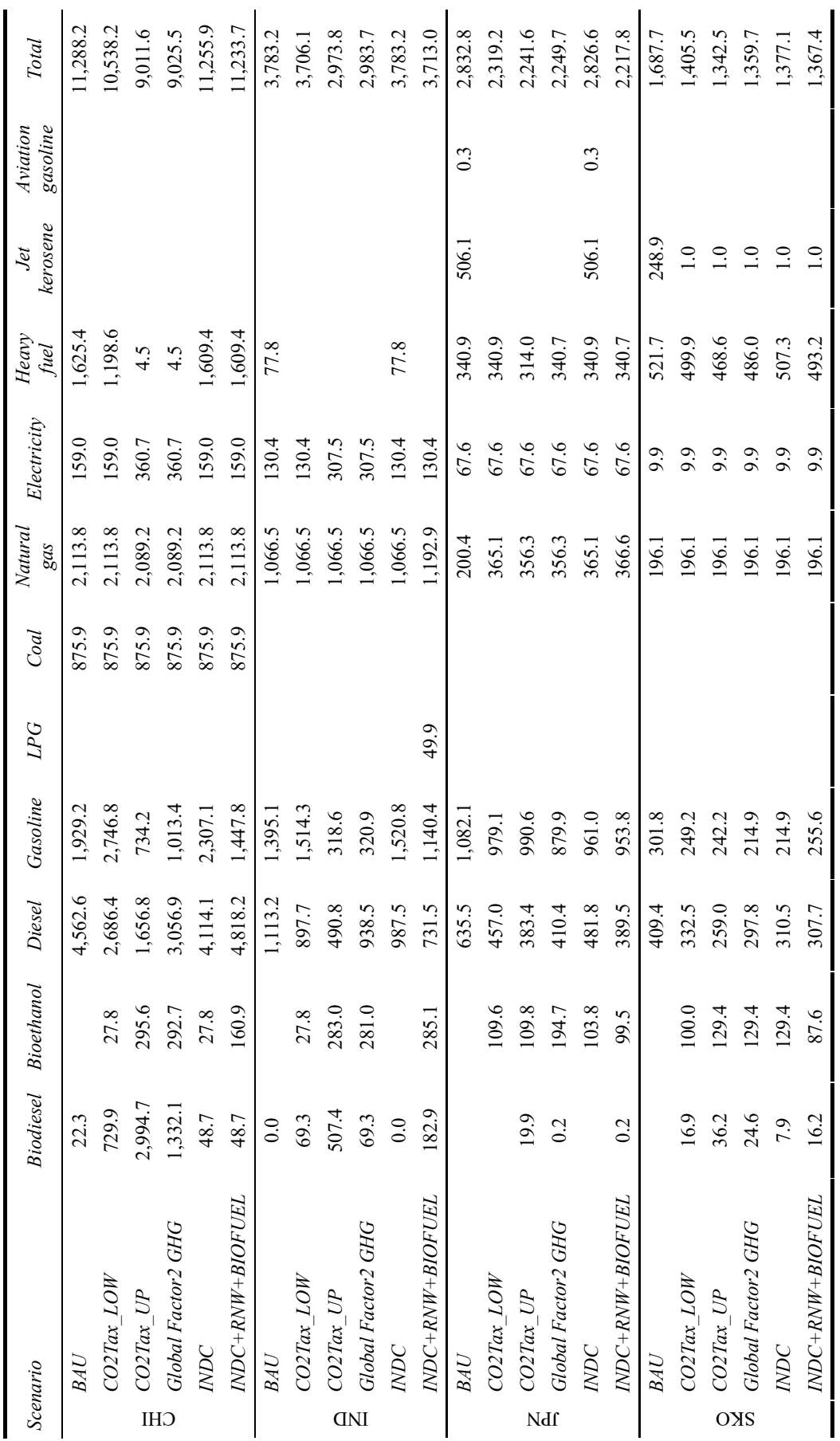

